\section{Objetivismo e izquierda nacional en Poesía civil}

Martín Baigorria*
A $r$

29-49

\section{Resumen}

En Poesía civil la interpretación político-económica en clave localista se remonta a la corriente de autores identificados con la izquierda nacional: Raúl Scalabrini Ortiz, Arturo Jauretche, Hernández Arregui así como también a varios momentos de la obra de Ezequiel Martínez Estrada. Pese a que estas influencias no se subrayan habitualmente, la incorporación de ese programa crítico constituye el momento más arriesgado del libro; particularmente en su penúltima sección vemos desfilar una serie de diagnósticos históricos dirigidos a poner
In Sergio Raimondi's Poesia civil the political-economic interpretation with a local perspective has a clear precedent in the essayists identified with the so-called "National Left-wing" or "Peronist Left-wing": Raúl Scalabrini Ortiz, Arturo Jauretche, Hernández Arregui, as well as many moments of Ezequiel Martínez Estrada's work. Even though these influences are not often acknowledged, the incorporation of this critical program embodies one of the most ambitious moments in Raimondi's book: particularly in its penultimate section, we can see a series of historical diagnoses which

*CONICET-Unqui. Correo electrónico: martin.rodriguezbaigorria@gmail.com 
en entredicho los axiomas clásicos del liberalismo económico. Esa rehabilitación de la izquierda nacional ubica la consigna objetivista "ideas sí pero en las cosas" dentro de una discusión que para Raimondi no habría sido aún saldada. Y viceversa: la traducción de la "cuestión nacional" en clave objetivista actualiza esa crítica, la convierte en una mirada novedosa en el contexto neoliberal de fines de los noventa.

Palabras clave: Poesía civil - objetivismo - izquierda nacional aim to question the classic axioms of economic liberalism. This retrieval of the "national left-wing" brings the objectivist motto "not ideas but in things" to a discussion which may have not already been closed for Raimondi. On the other hand, the objectivist rendering of the "national issue" updates this critique and turns it into something new in the context of neoliberal hegemony at the end of the nineties.

Keywords: Poesía civil - objectivism "national left"

\section{Fecha de recepción}

26 de noviembre de 2019

\section{Aceptado para su publicación}

13 de diciembre de 2019 


\section{Objetivismo e izquierda nacional}

Sabemos que Poesía civil discute varios aspectos de la experiencia de Bahía Blanca durante los noventa a partir de Marx y la crítica de la economía política ${ }^{1}$. Una parte de ese interés por el territorio tiene sus antecedentes en el Paterson de William Carlos Williams, el objetivismo argentino (El faro de Guereño y El guadal de García Helder) ${ }^{2}$ o el ensayo de Saer El río sin orillas, pero en particular la lectura político-económica más localista se remonta a la corriente de autores asociados a la izquierda nacional: Raúl Scalabrini Ortiz, Arturo Jauretche, Hernández Arregui, así como también varios momentos de la obra de Ezequiel Martínez Estrada. Pese a que estas influencias no se subrayan habitualmente ${ }^{3}$, la incorporación de ese programa crítico constituye el momento más arriesgado de Poesía civil, aquel en el cual se buscan articular contexto socio-económico y cultural, pasado y presente de la nación. Particularmente en la tercera sección de esta obra ("Para un discusión de la economía de exportación") surgen una serie de diagnósticos dirigidos a poner en entredicho los axiomas del relato liberal: la crítica del modelo agroexportador, la ilusión de progreso indefinido como consecuencia de la sumisión al capital extranjero, la importación cultural y el libre comercio, llegándose incluso hasta Rosas y el debate sobre el proteccionismo económico (Raimondi, 2010: 99, 101, 107, 109) ${ }^{4}$. Lejos de ser casuales, estas preocupaciones atraviesan todo el libro; se trata ante todo de releer una serie de controversias que permitirán reflexionar sobre la hipóstasis entre capital y territorio, el vínculo entre romanticismo y liberalismo en el siglo XIX, o la legitimación posterior de ese proyecto ideológico en el lenguaje y el espacio público cotidiano.

Poesía civil lleva así adelante una re-disposición de los temas de la izquierda nacional desde la perspectiva de la poética objetivista, lo cual supone también historizar esas mismas preocupaciones literarias. En el libro de Raimondi ambas perspectivas son de hecho inescindibles; análisis histórico-económico y lenguaje

1 Cfr. Porrúa, 2003; Kesselman et al., 2012; Avaro, 2016 [2007].

2 Dentro del objetivismo argentino deben mencionarse también a Martín Prieto, Daniel Samoilovich, Jorge Aulicino, Daniel Freidemberg, Osvaldo Aguirre y Mirta Rosemberg. Todos ellos fueron integrantes de la redacción del Diario de Poesía. En este trabajo nos limitamos a mencionar los libros de Helder, ya que ellos parecen haber sido la influencia más importante dentro de la poética de Raimondi. Cfr. Aguirre, 2014: 86.

3 Si bien de modo muy general, la única excepción sería García Helder (2007: 131-148). Raimondi menciona sin embargo explícitamente esas influencias (Aguirre, 2014: 86).

4 En orden sucesivo nos referimos a los siguientes poemas: "La naturaleza no es un Banco", "La historia se ha de escribir sobre una playa pavimentada", "Artículo 11 del contrato celebrado el 16 de marzo de 1896 entre el Estado Nacional y la empresa inglesa del Ferrocarril del Sud, de acuerdo a la ley n 3344", "LCI (Logística Comercial Internacional)", "Importación de libros en Buenos Aires, 1820", "El ciudadano selenita", "Literatura y Aduana". 
poético se sostienen en una doble premisa común: las filiaciones objetivistas del autor (localismo, realismo, lenguaje concreto en sus máximas posibilidades) responden al problema de la soberanía económica y cultural mientras que, por otro lado, las inquietudes nacionalistas permiten ampliar considerablemente los alcances de dicha poética, vinculándola con la historia y la economía política. Esa rehabilitación de la izquierda nacional ubica la consigna objetivista "ideas sí pero en las $\operatorname{cosas}^{\prime \prime}{ }^{5}$ dentro de una discusión que para Raimondi no habría sido aún completamente saldada. Y viceversa: la traducción de la problemática nacionalista en clave "objetiva" actualiza esa reflexión, la convierte en una mirada novedosa en el contexto neoliberal de fines de los noventa.

\section{Los "dos países" como problema literario}

El capital viene de lejos a Suramérica; los centros de riqueza que crea son excéntricos al trabajo y generan un ciclo de actividad que conduce como fin a la salida del rédito en calidad de materia prima también: de dividendo. Bancos, industrias, comercio, trabajan en función del prestamista incógnito. Su actividad está regulada por la utilidad del usufructo, y no de la utilidad pública, de las necesidades de la vida interior del país. Esa forma de gravitar alrededor de un centro remoto, está en la relación de satélite a planeta y de colonia a metrópoli (Martínez Estrada, 1968: 94).

La disociación entre intereses económicos y aspiraciones colectivas es un tema muy presente en Radiografía de la Pampa (1933) de Martínez Estrada, retomado a fines de los cincuenta por otros ensayistas como Jorge Abelardo Ramos, Rodolfo Puiggrós, Hernández Arregui o Jauretche ${ }^{6}$. Partiendo de Marx, estos autores reformularon esa discusión combinando de distintas maneras el problema de las relaciones entre base económica y superestructura cultural con el conflicto de clases y las teorías de la dependencia. La exclusión del peronismo había puesto a la "cuestión nacional" en el centro de la reflexión; este era el tema clave, reconocible en todas las formas de la conciencia y la vida social: ya sea en la puja del industrialismo frente al modelo agroexportador, la tensión entre el mercado interno y el mercado mundial, los hábitos de consumo de los ciudadanos con sus modelos culturales implícitos, o al nivel

\footnotetext{
5 Cfr. la traducción del Paterson publicada por Raimondi en el segundo número de la revista 18 whiskys.

6 Nos referimos principalmente a Imperialismo y cultura (1957), La formación de la conciencia nacional (1960) de Hernández Arregui y a Los profetas del odio y la yapa (1957) de Jauretche.
} 
de la conciencia lingüística y sus manifestaciones en la educación, el arte, etc. ${ }^{7}$ Con un estilo más polémico que sistemático esos textos apuntaban a una misma pregunta, ¿cuáles son los vínculos entre un modelo de desarrollo económico y la identidad cultural de un territorio? ¿Cómo se influyen o interfieren entre sí?

Pero después de los setenta, Marx y el peronismo de izquierda fueron sometidos a una larga serie de cuestionamientos, revisiones y ajustes de cuentas; las tesis del pensamiento nacional quedaron así bajo un halo de sospecha que advertirá sobre sus inclinaciones reaccionarias o sus vinculaciones con la violencia política, convirtiéndose a lo sumo en una pieza de museo antes que en un concepto crítico capaz de explicar el presente ${ }^{8}$. Esa marginalización puede intuirse en el propio planteo del libro de Raimondi: su estrategia apunta a recuperar un conjunto de interrogantes con sus premisas y argumentos sin detenerse en sus representantes o simbología más evidentes. O basta si no con releer el Río sin orillas - un texto de los noventa muy cercano a Poesía civil a nivel temático y estético- donde también abundaban los reproches al nacionalismo ${ }^{9}$. No casualmente todos esos debates reaparecen en el prólogo a la segunda edición del libro:

(...) esos son momentos de una narrativa mayor y polémica: la de los dos modelos de producción. A menos que se crea que la disputas en torno al rumbo productivo de una nación suceden en un orbe indiferente a la vida social de cada día (...). El supuestamente ineludible destino agro-exportador no sólo está inscripto en las formas particulares de la dieta alimenticia de la sociedad; se inscribe también con mayor, menor o nula conciencia- en la decisión en torno al uso de una palabra o a la elección de una imagen (Raimondi, 2010: 12).

\footnotetext{
7 "Toda la clase principal se disciplina dentro de la ideología; la colonización económica -el progreso como afirmación del país incluido en la división internacional del trabajo y su correspondiente negación como integración del todo nacional- se integra con la colonización pedagógica, pues todo el instrumental del pensamiento, desde la alfabetización al periodismo, el libro, la cátedra y la universidad, irradian hacia el seno de la sociedad las características culturales presupuestadas ideológicamente" (Jauretche 1957: 290).

8 Críticas similares u otras referidas al determinismo, al estatuto mítico de los "dos países" y el "anti-intelectualismo" pueden hallarse en El revisionismo histórico argentino como visión decadentista de la historia nacional de Tulio Halperin Donghi (2006 [1970-1997]), Los deseos imaginarios del peronismo de Juan José Sebreli (1992 [1983]), Nuestros años sesentas: la formación de la nueva izquierda intelectual en la Argentina, 1956-1966 de Oscar Terán (1991), los artículos de Beatriz Sarlo, "La perseverancia de un debate" (Punto de vista n 18, 1983, "Cultura nacional y cultura popular") y "La izquierda ante la cultura: del dogmatismo al populismo" (Punto de vista n²0, 1984, "La izquierda crisis de una cultura política").

${ }^{9}$ Cfr. Saer, 1994.
} 
Una vez más, el problema es el vínculo entre un modelo productivo y su identidad cultural. Los distintos elementos de una lengua serían así parte de una organización que presupone una jerarquía no siempre coherente y uniforme; puede ser al nivel de la relación sujeto-predicado, en la elección de una metáfora o un adjetivo, en torno a estas alternativas lingüísticas entran en tensión distintas concepciones del país tanto al nivel de su realidad práctica como en su imaginario, historia, figuras ejemplares, etc. Muy a contracorriente del clima cultural imperante, esto suponía leer "Sobre la corrupción" de García Helder desde la perspectiva de Scalabrini Ortiz ${ }^{10}$ : mientras para el Helder de fines de los ochenta lo importante sería la atención al momento puntual frente a ese "hedor de pescados exangües/pudriéndose al sol sobre los mostradores/ de venta, en la costa", para Scalabrini esos pescados eran también "moléculas inseparables del organismo económico"11, moléculas cuyo carácter de mercancía y rol práctico en la sociedad obsesionarán a Raimondi. La figura intermitente del "poeta menor" juega acá un rol significativo; personaje escindido entre la biblioteca de los clásicos y las necesidades del ciudadano promedio, mezcla de funcionario raso y transeúnte casual. Toda la enunciación del libro se basa en la observación de aspectos poco atendidos de la realidad económica cotidiana: desde las condiciones laborales y los cambios tecnológico-productivos hasta ordenar la casa, una consulta en el dentista, etc. ${ }^{12}$.

10 "Puede ser que/haya en cada cosa un gesto, una cifra,/y que de las piedras se infiera/ perdurabilidad, fugacidad de los insectos/y la rosa. Que perfumes,/sonidos, colores se correspondan,/o que arrojado contra los pinos endebles/el viento nos haga una advertencia./ Incluso que cualquiera de nosotros/se crea sacerdote de estos y otros símbolos,/cualquiera capaz de convertir/lo concreto en abstracción, lo invisible/en cosa visible, lo familiar,/lo inerte, lo alejado en sus contrarios./Sea o no esto así, de algo estoy seguro:/no me conviene interpretar mensajes en nada,/menos aún, en este momento,/descifrar eso que las rachas del aire/traen hasta aquí -zumbido de moscas verdes,/hedor de pescados exangües/pudriéndose al sol sobre los mostradores/de venta, en la costa" (García Helder, 1990: 43). Raimondi discute también con algunos textos de Helder; compárese por ejemplo "Una alegoría" (García Helder, 1990: 42) con "De la caverna como imagen de la biblioteca" (Raimondi, 2010: 50). De manera inversa, La vivienda del trabajador, publicado por García Helder en 2008, puede ser visto como un texto mediado por la lectura de Poesía civil.

${ }^{11}$ El siguiente pasaje ofrece algunas conexiones sugestivas entre Scalabrini Ortiz y el tipo de conocimiento reivindicado por Raimondi: "El alma de los pueblos brota de entre sus materialidades, así como el espíritu del hombre se enciende entre la inmundicias de sus vísceras. No hay posibilidad de un espíritu humano incorpóreo. Tampoco hay posibilidad de un espíritu nacional en una colectividad de hombres cuyos lazos económicos no están trenzados en un destino común. Todo hombre humano es el punto final de un fragmento de historia que termina en él, pero es al mismo tiempo una molécula inseparable del organismo económico de que forma parte. Y así enfocada, la economía se confunde con la realidad misma" (Scalabrini Ortiz, 2001: 5).

${ }^{12}$ La descripción del cangrejo en "Excursión por la ría" se acerca bastante a esa voz: "La lateralidad al fin tiene su parte de gracia,/y tal vez no sea en nada incompatible/con el ner- 
De allí que en los términos de esta poética el detalle objetivista no tenga aún una historia, precisamente en el sentido en que lo señalaban los autores de la izquierda nacional: este configura más bien un vacío, un momento no narrado por la historia oficial -medios masivos, academia, etc.-; no sugiere imágenes trágicas ni heroicas, carece de brillo intelectual o estético pero no por ello es menos determinante en términos sociales, tal como puede verse en "La historia se ha de escribir sobre un playa pavimentada":

Lo que habría que ver desde aquí no es la estólida definición vertical de los galpones hechos ladrillo a ladrillo sino por el contrario su dispersión horizontal luego del efecto de un muy eficaz explosivo accionado en condiciones verosímiles de precaución. El número enorme de metros cuadrados que correspondieron ayer al Estado y antes de ayer al Cangrejal deberá convertirse en una amplia explanada de cemento y vacío: sólo así podrá quedar despejado el paisaje y recién entonces se podrá imprimir sobre su nada la imagen del nuevo proyecto de los sueños: contenedores sobre contenedores sobre contenedores sobre contenedores. Se trata de ofrecer la ilusión de que es posible empezar de nuevo, y por lo tanto adecuar, como se hizo un siglo atrás con este inhóspito lugar desde las exigencias de la empresa de ferrocarril, un pasado equivocado a un porvenir cuyo esplendor ya ha sido comprobado en otras latitudes. Es decir: el futuro existe, si bien por ahora está a 12 o 16 horas de avión. (Raimondi, 2010: 100).

Esta es la historia del "Cangrejal", zona costera donde ahora funciona el polo petroquímico de Bahía Blanca, convertida a fines del siglo diecinueve en puerto estatal gracias a la influencia del Buenos Aires Great Southern Railway (o Ferrocarril del Sud). La voz del poema pide concentrar la atención sobre un aspecto contra-intuitivo del paisaje portuario: no "la estólida / definición vertical de los galpones", inmediata a la vista, sino su emplazamiento dentro de un territorio cuyo usufructo pasó a manos de la renta privada. Esos distintos momentos de la historia local se hallan sin embargo compartimentados y acumulados desordenadamente al igual que esos "contenedores / sobre contenedores sobre contenedores $(\ldots)^{\prime \prime}$; sus nexos sociales y económicos se sustraen al reconocimiento inmediato

viosismo exasperado en detalles/y la buena visión de sus ojos compuestos./(...)/Un cuerpo que no es cuerpo sino una parte y otra parte y otra parte y apéndices,/sale al sol del mediodía sobre la isla Bermejo" (Raimondi, 2010: 96). 
de los transeúntes. ¿Cómo lidia Raimondi con ese problema? A la manera del objetivismo, no se hace hincapié en las emociones o en los actores históricos, con su respectiva identidad y connotaciones ideológicas; la presentación de las tareas de demolición junto a la explicación del cálculo logístico asumen una perspectiva cercana a la pedagogía anónima del capital"13: "sólo así podrá quedar despejado el paisaje/y recién entonces se podrá imprimir sobre su nada/la imagen del nuevo proyecto de los sueños". El relato del progreso funciona como una tabla rasa en el plano material y simbólico, luego transformado en tema de análisis geopolítico mediante otra referencia que sitúa el futuro del país "a 12 o 16 horas de avión". La precisión de las imágenes, los argumentos y las comparaciones históricas subrayan la distancia que separa a ese discurso de la realidad.

De este modo, mientras en un libro como El guadal (1993) el argumento y el relato aparecían dispuestos en función del paisaje yendo rara vez más allá, en Poesía civil esos elementos intervienen activamente sobre él ${ }^{14}$. La sugerencia prescriptiva con la cual arranca este texto apunta a ese problema: ¿qué es lo que debe verse frente a un paisaje de galpones? La pregunta plantea una tensión con un modelo cultural e ideológico dominante al nivel de la vida cotidiana:

Esto no es Florencia. No fue Florencia. No será

Florencia. Vayamos en auto si quieren, lleguemos

al borde mismo del muelle y veamos ya no el cerúleo

mar sino el barro canceroso de las islas de la ría

\footnotetext{
${ }^{13}$ Cfr. Kesselman et al., 2012; Rubio, 2012: 14-23. En el caso de la poesía de los noventa, otra lectura de la izquierda nacional puede hallarse en el ensayo de Alejandro Rubio "Antiintelectualismo" (Rubio, 2014: 76-79). Su libro Rosario retoma también algunas cuestiones planteadas en Poesía civil. Cfr. "Los mitristas" (Rubio, 2005: 9). En su ensayo sobre la poesía de Martín Gambarotta, Raimondi menciona a Punctum (1996) como otro precedente importante (Raimondi, 2014: 34-45).

${ }^{14}$ Es una dificultad que el objetivismo buscó resolver de distintas formas (cfr. 40 watts de Oscar Taborda, La vivienda del trabajador de García Helder o la trilogía de Aguirre, El campo). En la entrevista del Diario de Poesía Raimondi se refiere a la cuestión: “Creo que descubrí que no se trataba de pensar en términos de paisaje. Mejor, aprendí de a poco a advertir todo lo que esa noción deja afuera. (...) la perspectiva del paisaje se funda privilegiadamente en un nivel de lo visual, y mi experiencia era más auditiva, o en todo caso, lingüística: (...) relatos que en un punto destruían el paisaje que yo más o menos podía ver, o lo dotaban de densidad" (Aguirre, 2014: 88). Por otro lado, ese matiz con el objetivismo se remonta al modo en que Raimondi traduce la consigna de William Carlos Williams, "not ideas but in things", al descartar el "no" e introducir un "si" ausente en la expresión original en inglés. Al menos implícitamente, la expresión afirmativa le da mayor protagonismo a las premisas intelectuales e ideológicas que constituyen una imagen: "(...) lo abstracto se ha de comunicar desde un nivel de lo material, de lo concreto" (Aguirre, 2014: 84-85). Para la traducción de Raimondi cfr. el número "3-4" de la 18 whiskys (AA. VV., 1993). Ya en Paterson y varias otras composiciones Williams retomaba esa consigna con distintas variaciones sintácticas, cambios de versificación, etc.
} 
en la que guanacos habitan y ñandúes y peludos y uno o dos hombres con minúscula y un lanchón. "Aunque el término hombre es aplicado a todos, pertenece propiamente sólo a aquellos que por medio de las disciplinas liberales están convenientemente educados para la formación humana (humanitas)" (Cic. De rep. 1, 17, 28, tr. de Antonio Camarero). Por entre las columnatas algo griegas de la UNS descendieron esos Hombres íntegramente formados, conocedores del obligado servicio de la literatura para la moral y la virtud, y de su fruto inequívoco en beneficio del bien común: eruditio libero digna. Esta es su ciudad. Pasamos ahora frente a una pared que exhibe el grafito CVM. Me Ileva horas explicar que no se trata de la preposición latina sino de la sigla del Club Villa Mitre, cuyo equipo de fútbol milita por el momento en el campeonato de la B Nacional. (Raimondi, 2010: 80).

El cuestionamiento a la "humanitas" burguesa se halla emparentado con la reflexión de Jauretche:

El letrado ve las cosas de otra manera. (...) Piensa en términos de principios y no en términos de hechos, y le interesa que esos principios jueguen en el mundo abstracto a que pertenece, al margen de lo que resulta para sus paisanos (Jauretche, 1957: 163) ${ }^{15}$.

A Raimondi le interesa particularmente esa discusión con la cultura de la elite liberal, aludida más de una vez a lo largo del libro. Pero esta es una querella que Poesía civil elige librar en el terreno del adversario; el recurso clásico de la derivación puede utilizarse así para poner en duda la presencia de un paradigma cultural

\footnotetext{
15 "La Cultura, la Civilización, los Derechos del Hombre se refieren, en la mentalidad de los metropolitanos, en sus bocas, en lo íntimo de su pensamiento, y más que en su pensamiento en su subconsciente, a una humanidad de muy estrechos límites. (...) Los demás pertenecemos a un suburbio de su ciudad humana; tal vez estemos más cerca que los chinos o los annamitas, por tan lejos como los egipcios, los griegos o los yugoslavos. (...) Cuando habla de Libertad habla de su libertad y la de los suyos; cuando habla de Economía, se refiere a los efectos que percibe y los que perciben su gremio, su clase, su ciudad, su provincia, su nación" (Jauretche, 1957: 163). Cfr. también la conferencia de Jauretche en la Universidad Nacional del Sur en 1974: "Porque el sabio acumula sus conocimientos como el rico su dinero y los ama y es prisionero de ellos y le cuesta mucho romper con la superstición de su sabiduría, juzgarla, ponerla en tela de juicio. Y aquí no se trata de ponerla en tela de juicio sino probarla en contacto con la realidad" (Jauretche, 2013: 69).
} 
europeo -la Florencia renacentista-, asociado a la recuperación del ideal humanista. Nuevamente el problema es aquello que aparece ante los ojos, esta vez marcado por la tensión entre una realidad inmediata y su codificación estética, entre el "barro canceroso de las islas de la ría" y el "cerúleo mar". La primacía del ideal es una prerrogativa subyacente en la mirada de esos letrados, caracterizados como los habitantes naturales del lugar: "Esta es su ciudad"; en tanto representantes de la "Humanidad" son ellos los que definen cuáles son los valores culturales virtuosos. Se trata de una perspectiva de clase interpolada con la cita de autoridad de un aparato textual erudito, en abierto contraste frente a esos "hombres" junto a un "lanchón": el sintagma latino, la traducción del especialista, la definición de Res publica que excluye al ciudadano común de las "disciplinas liberales" y la "formación humana". En la segunda mitad del texto, la escena de las escalinatas parece ser un momento fundacional tal vez ubicado a principios de los años cincuenta; pero más allá de los trazos irónicos y la distancia en el tiempo, ella no deja de tematizar un debate muy actual en torno a los vínculos de la "educación superior" con su propio territorio, ya sea al nivel de su historia o de sus problemas cotidianos.

Otra arista de la cuestión puede hallarse en "Pintores dominicales en Puerto Piojo": al menos desde hace cuarenta años esos paisajistas ven siempre las mismas imágenes - "la lancha de los pescadores", "las gaviotas" y "los marinos"- que excluyen sistemáticamente "los elevadores ingleses / de chapa ayer, hoy los silos y el muelle Cargill / o la serie de tanques del proyecto Mega" (Raimondi, 2010: 116). En esos estereotipos no hay sólo una inclinación estética, sino una forma de percepción especialmente "educada" para no captar las transformaciones de su entorno material; estas últimas son datos marginales casi sin peso en la conciencia de los ciudadanos ${ }^{16}$. Se vuelve así evidente la vigencia de un modelo perceptivo con una historia propia, que llevará a Raimondi a discutir con la tradición romántico-liberal del siglo diecinueve.

\section{Romanticismo y liberalismo económico}

En Poesía civil esas sucesivas disociaciones entre realidad e intereses económicos, entre realidad y expresiones culturales, son también procesos históricamente ligados a la recepción del romanticismo y la expansión del capital en la región pampeana. Como se señala en "Importación de libros en Buenos Aires, 1820", la llegada de la literatura romántica y la teoría económica junto a la exportación de materias primas son dos momentos claves en la definición de la identidad

\footnotetext{
${ }^{16}$ No es casual tampoco que la discusión con Martínez Estrada retome estos cuestionamientos; nuevamente el problema es una conciencia histórica inmersa en el "trajinar de esencias y leyes / moralmente eternas" refractarias a los interrogantes del contexto histórico (Raimondi, 2010: 85).
} 
local; allí se conjugan el librecambismo y el anhelo de incorporación al mundo con el mito de una naturaleza convertida en metáfora del progreso (Raimondi, 2010: 107). Se trata de dos fenómenos concomitantes aludidos varias veces en el libro: puede ser la concepción de la poesía como dominio de valores eternos y la imposición del principio de propiedad en una región del cono sur ("Ante un ejemplar de Defense of poetry..."), la mirada estrábica de la generación del ochenta en "Cotización del Endymion" -que observa los vagones de trigo como si fueran espigas doradas salidas de La Eneida-, o una escena donde Roca anuncia con imágenes hiperbólicas un progreso ajeno a cualquier noción de soberanía económica (Raimondi, 2010: 21, 114, 101) ${ }^{17}$.

El principal problema de esa disociación entre ideales y territorio es que ella produce una falsa identidad entre ese mismo territorio y algunos intereses demasiado particulares. Una vez más la imagen objetivista es el punto de partida para un análisis detallado de la cuestión: en "La Naturaleza no es un Banco" se discute por ejemplo la similitud natural entre el brillo de "un haz de trigo" y el "oro"; metáfora que identifica el mito de la naturaleza proveedora con la idea de una riqueza material infinita (Raimondi, 2010: 99) ${ }^{18}$. El cuestionamiento que -siguiendo Pound-García Helder oponía a las abstracciones del simbolismo será retomado por Raimondi en su crítica a la ideología romántica; en ambos casos se apunta a desmontar las connotaciones estáticas de eternidad y perdurabilidad que esas poéticas creen entrever en los elementos del mundo exterior (García Helder, 1990: 42). Pero este no es el único movimiento, porque a la vez el poema reformula también una idea de Martínez Estrada: el primer crédito no fue emitido por la tierra, sino más bien por la literatura al darle una esencia ahistórica a un recurso material limitado ${ }^{19}$, lo cual

${ }^{17}$ Las connotaciones sempiternas del romanticismo pueden reconocerse en la retórica de Bartolomé Mitre: "Verdaderamente señores, el capital inglés es un gran personaje anónimo cuya historia no ha sido escrita aún. (...) los ingleses saben que los pueblos no mueren ni quiebran, creyeron en la inmortalidad de su capital; $y$ hoy lo ven resucitar en forma de rieles, de locomotoras y carbón de piedra, para abrir el camino del desierto prometido, que poblarán pronto los inmigrantes sirviéndoles de baqueano el ingeniero" (Citado en Halperin Donghi, 1995: 333). . También para Mitre el capital es hipóstasis de una de naturaleza cristianizada, forma eterna capaz de resucitar una y otra vez para abrir el camino del progreso y la civilización.

${ }^{18}$ En el libro esta concepción puede llegar incluso a la minuciosidad ideogramática. Véase sino en "URGA" la objeción formulada frente a la simbología del Partido Comunista: "(...) y no, no es una hoz sin mella lo que se ha de pintar / en la pared, a menos que sirva para reconsiderar el hecho / en relación al cereal que desde lo alto por un tubo en el muelle / a la bodega cae $(. . .)^{\prime \prime}$. La imagen de la hoz y el martillo aparece reenviada hacia la discusión sobre "la cuestión agraria" planteada entre otros por Hernández Arregui, 2011: 318-323.

19 "La tierra fue bono de crédito, haciendas que se multiplicarían fantásticamente en lo futuro para la esperanza; esta, su hipoteca" (Martínez Estrada, 1968: 14). Horacio González ve en Martínez Estrada a un predecesor de la sociología y el ensayo, Christian Ferrer a un pensador anti-sistema, anarquizante (cfr. González, 2001, 2004; Ferrer, 2014). La relectura 
conduce a un choque entre la realidad concreta y las fantasías de ese "modélico destino" agro-exportador:
(...) Se importó para exportar
no para no importar más. Un año o dos sin nubes a la vista
y la trilladora urgida de algún repuesto, y el número
ingente de la deuda, blancos huesos, seco el junco
del fisco junto al arroyo seco, una escena romántica,
al azar del modélico destino liberal que copia y copia
como la literatura de sus ociosos, mucho, mucho y mal.
(Raimondi, 2010: 99).

Es otra coincidencia clave entre objetivismo y pensamiento nacionalista: no comprender las características de un territorio y una coyuntura particulares va asociado a una estética deliberadamente idealizadora, abstracta u opaca. En la crítica de la izquierda nacional esto producía una inversión en el concepto de imitación cultivado por los grupos letrados: como puede verse en los versos finales de este poema, ella no es un vicio atávico de las clases populares (el folletín costumbrista, etc.) sino un problema de esos sectores minoritarios, cuya comprensión del territorio termina colapsada por la acumulación de mediaciones abstractas. Esa "imitación grotesca de lo exterior" (Jauretche, 1957: 169) afecta a las formas mediante las cuales se estructura la realidad ${ }^{20}$. En "Literatura y Aduana" se plantea el mismo problema a través de la oposición entre la "sofía de Minerva" y la "inteligencia del rastreador" -el saber culto y el conocimiento del territorio-: hay ahí dos perspectivas de clase, enfrentadas tanto en sus intereses como en el modo en que se organizan los hechos externos (Raimondi, 2010: 109). Por eso, si la izquierda nacional había polemizado con el grupo Sur apuntando a estas

\footnotetext{
en clave materialista corresponde a Raimondi. Así mismo, además de la reflexión histórica o el estudio del espacio urbano, las similitudes estilísticas con la retórica de Martínez Estrada constituyen otro de los aspectos que emparentan a Poesía civil con Radiografía de la pampa, temas que quizás merezcan un estudio aparte.

20 “(...) la sociedad oligárquica no ha dejado en su estela histórica más que parálisis, manías imitativas, poesías traducidas, argentinos indiferentes con su país" (Ramos, 1985: 53). Es una crítica también planteada por Jauretche que incluso lo lleva a discutir con el primer peronismo: "En la imitación grotesca de lo exterior, ésta siempre se hace como transferencia y así se transfiere el nombre, pero no el buen sentido con que en el ejemplo propuesto, Europa, se conserva la toponimia. Es que la copia es siempre para contrariamos, nunca para favorecemos. Y esto de la toponimia artificial está tan metido en el entresijo cultural que nos han hecho, basta que los descamisados cayeran en lo mismo. ¿Puede haber disparate más grande que haber cambiado los nombres naturales y lógicos de los ferrocarriles por estos otros que nada tienen que ver como elementos de identificación, como los que habían nacido como aplicación de una geografía elemental? ¡Y esto lo hicieron los mismos que los nacionalizaban!" (Jauretche, 1957: 169).
} 
cuestiones, Raimondi recuperará esos cuestionamientos y les conferirá un marco cultural e histórico más sistemático, remitiéndolos a la recepción del romanticismo en el Río de la Plata.

Pero la discusión de Poesía civil con esta ideología literaria posee ramificaciones en el presente, en la medida en que sus imágenes cristalizadas devienen el núcleo identitario de las concepciones económicas dominantes. En "La draga" se pone de nuevo el foco en las contradicciones del modelo agro-exportador:

Uno de los problemas del país es y seguirá siendo la posesión inevitable de una de las cinco praderas más fértiles del mundo y el empeño menos natural en hacer de ella la esencia económica de su ser de acuerdo a prerrogativas largamente históricas confundidas con un destino de rigor frente al cual nada es dado modificar (...).

(Raimondi, 2010: 110)

Mientras en la "Naturaleza no es un banco" el trigo era convertido en fuente de una riqueza infinita, en este poema vemos cómo esa hipóstasis se ha convertido en una "esencia económica", parte de un destino natural e inmodificable. Pero es necesario agregar que, en el caso de "La draga", la irrupción de las tareas de remoción y perforación de escombros en la ría bahiense apunta a no quedarse en la denuncia ya conocida, por muy elocuente que ella sea; una vez más, no sólo se trata de impugnar ciertas concepciones naturalizadas sino de oponerle del modo más chocante su propia realidad. Esas referencias materiales producen un anticlímax recurrente en la retórica del libro, ya sea mediante la pregunta "¿cómo abaratar costos?", la imagen de los "contenedores / sobre contenedores sobre contenedores (...)", las onomatopeyas, una referencia bibliográfica hiper-codificada, o una doble negación cercana a la oralidad ("Se importó para exportar / no para no importar más"). En todos estos casos lo que preocupa a Raimondi es cómo invertir la relación de fuerzas entre las formas más fetichizadas de la experiencia social y el registro de hechos o percepciones provenientes de la vida diaria (Raimondi, 2010: 110, 25-26, 106, 80, 99).

\section{Saber, lengua y contexto local}

Las clases altas "copian y copian mal", no comprenden el contexto pero ¿qué hace entonces el pueblo? Para hablar de esto, Raimondi rescata algunas situaciones centradas en la resolución de problemas prácticos. Como en su trabajo en el Museo del Puerto de Ingeniero White, también en estos textos se recorre el espacio de una historia no documentada por la cultura oficial. En "Escuela Téc- 
nica 'Carlos Gallini', 1992" vemos a Mladen Radetich -un docente e inmigrante autodidacta- fabricar aparatos técnicos dentro de su taller "fuera del horario laboral"; en "Modificación en la alimentación de las locomotoras..." un híbrido de maíz, trigo y leña reemplaza el carbón Cardiff requerido por los trenes ingleses (Raimondi, 2013: 12-13). Los dos exponen una interacción imprevista entre materiales y saberes reutilizados en condiciones locales: puede ser una máquina de vapor o la invención de un nuevo combustible, ambas escenas recrean el programa de sustitución de importaciones en el plano de la microhistoria. Así como en "Escuela Técnica..." ese inmigrante no puede esperar la llegada del último manual, tampoco deja de ser significativo que en "Modificación..." no haya ninguna persona aludida; como si se pasara del sujeto al objeto de la Historia, el poema detalla paso a paso la fabricación de un insumo:

Mismo el mecanismo: astillas, empapada estopa
de kerosén, fuego hasta la lámina de agua
que circunda el cielo del horno, fuerza y presión
del vapor acumulado en la caldera, arrojado
sobre los émbolos en los cilindros que lleva
sobre el liso riel dinámica a la rueda, que gira.
(Raimondi, 2010: 113).

Estas son imágenes de un debate no zanjado: frente a la idea de que el progreso posee como premisa la incorporación constante de elementos provenientes de los grandes centros capitalistas (créditos, inversiones, ideas), la visión de la izquierda nacional plantea un uso estratégico de esos materiales, poniendo énfasis en las necesidades del desarrollo local ${ }^{21}$. El correlato literario de estas escenas podría ser la poesía de Leónidas Lamborghini, quien durante los años cincuenta reelabora aspectos claves de la poética de T.S. Eliot (la oralidad, la noción de discurso dramático del modernismo) para hablar del peronismo y su proscripción tras el golpe militar del ' 55 .

Tampoco la lengua es ajena a esta problemática, como puede verse en "Los enemigos son Andrés Bello y el Chacho" (Raimondi, 2010: 119). En ese texto el

\footnotetext{
${ }^{21}$ Para una discusión con esta perspectiva, Gramuglio dice: "El psicoanálisis, la antropología, los estudios culturales, y a veces también la historia tienen la virtud de enseñarnos de mil modos que en la constitución de las identidades, sean subjetivas, sean culturales, la intervención de alguna alteridad es indispensable. Ante ese dato persistente, la mera postulación de un esencialismo original refractario a todo reconocimiento de un agente exterior vendría a brindar, más que una hipótesis antagónica en campos siempre abiertos a la controversia, un síntoma elocuente del desasosiego que tal antinomia, la de una otredad necesaria para la configuración de lo propio, acarrea consigo. Es que no inevitable deja de ser, esa antinomia, una fuente inagotable de conflictos, y la dialéctica que supone, uno de los más persistentes malestares de la cultura" (2014: 337).
} 
academicismo es cuestionado desde el punto de vista de la localía: "el idioma se mueve y varía en el gusto de cada lengua"; privilegiar la "pasión" antes que la "norma" equivale fundamentalmente a "escribir tal como el pueblo pronuncia". La conjunción del letrado y el iletrado apunta a desactivar la acusación de "anti-intelectualismo". Digamos que no todo es civilización y barbarie; siendo de mundos culturales opuestos, Bello y Peñaloza comparten concepciones muy cercanas en lo que hace al uso de la lengua. El Chacho se asemeja al rey hegeliano, utiliza la lengua como un instrumento maleable sin preocuparse demasiado por sus normas y convenciones: con un garabato que se asemeja a su nombre "pone los puntos sobre las íes" para poner las cosas en marcha. Bello, por su parte, entiende esta perspectiva porque, lejos de ser producto de la ignorancia, ella responde -como en el caso de Mladen Radetich- a necesidades sociales concretas, surgidas en un tiempo y espacio no homologable al del puerto o la metrópoli europea. Poesía civil discute así nuevamente con las normas de la elite intelectual y la propia recuperación de la memoria revisionista no es un aspecto menor de la lectura histórica propuesta por el libro; casi podría decirse que Raimondi sugiere una genealogía tendiente a conectar la revuelta federal de Peñaloza con la reivindicación noventista del habla: el lenguaje romántico y sus estribaciones puristas en el presente son su común enemigo.

También entonces la cultura se comprende como un territorio concreto, donde se da un conflicto entre la elite, capaz de imponer modelos y sanciones de distinto tipo, frente a aquellos subordinados a ese orden social. Pero no se trataría simplemente de quedarse en un mero gesto de resistencia. Si para Raimondi la lengua es parte de la dialéctica existente entre sociedad civil y Estado, esto debe ser también un asunto de gobierno. Sabemos que el idioma varía en cada región al estar marcado por "condiciones atmosféricas particulares / suelos con gran porcentaje de óxido / de hierro, limosos, arenosos o no, variedades / dialectales en uso, historia y recursos económicos (...)" (Raimondi, 2010: 88). Por eso en "Shklovsky en diálogo con los productores de papa" se recomienda fundar centros de Estudio del Lenguaje Poético con un criterio regional similar al aplicado por el Instituto Nacional de Tecnología Agropecuaria, "según la idea clave / de que a lugares diversos, diversos problemas, / tiempos diversos, errores, herramientas, soluciones $(. . .)^{\prime}$. La lengua es una "herramienta" atravesada por un cúmulo de determinaciones que no dejan de ser también disputas abiertas. Surge así una respuesta al problema antes planteado por "Civitas y humanitas": al concentrarse en las particularidades idiomáticas y expresivas, la conciencia formalista puede ayudar a establecer conexiones entre los saberes más específicos, sus condiciones materiales y la comprensión de un entorno social. Esta sería una manera de convertir la "inteligencia del rastreador" en una política de Estado destinada a pensar una "literatura útil y nacional" (Raimondi, 2010: 109), asunto que parecería volver en el libro aún inédito Para un diccionario crítico de la lengua: 
Releer la oratoria derrotada en los debates de la cuestión capital La discusión enfática previa a la instalación de la naturaleza. Analogías apopléjicas o macrocefálicas del orbe de la medicina para dar cuenta del desequilibrio enfermo de la concentración. (Raimondi, 2013a: 84) ${ }^{22}$

\section{Estilo y hegemonía}

Desde el punto de vista del estilo, la pregunta es entonces cómo intervenir en los paradigmas definidos por la elite liberal. Dilema que tal vez se podría responder con otro interrogante: ¿por qué Raimondi, el poeta materialista, prefiere recurrir a los clásicos? En los términos de sus preocupaciones estéticas y políticas, esa opción no es solo un gusto individual. Y también sería erróneo pensar que en Poesía civil las formas supuestamente estables de la tradición tendrían como finalidad la preservación de modos de vida acosados por las transformaciones del neoliberalismo: no hay en el texto ningún anhelo tendiente a conservar el pasado; la comprensión de una coyuntura socio-económica y sus premisas históricas no necesita apelar a la nostalgia. Otra posibilidad sería ver esa preferencia como una reformulación de la crítica de la izquierda nacional en función de la etapa democrática iniciada en 1983. Conocemos el lugar central de la literatura greco-latina en el canon; según el planteo marxista tradicional ella representa los valores intemporales y abstractos constitutivos de la ideología burguesa; con esas formas y tópicos se enunciaron las aspiraciones más ambiciosas de la elite, cuyos desvíos suponían la barbarie y la auto-destrucción ${ }^{23}$. Y si bien la izquierda nacional comparte esa sospecha, Raimondi sabe -tal vez debido a su formación en la educación pública- que la versión de los clásicos idealizada por el canon liberal olvida con demasiada rapidez sus elementos prosaicos, realistas u obscenos (como puede verse en su Catulito). Por otro lado, como ya lo indica el título del libro, se trata de plantear estas discusiones dentro de un contexto político muy diferente al del discurso nacionalista surgido durante la proscripción del peronismo. En Poesía civil la voz del "poeta menor" no habla desde la exclusión sino que asume una condición ciudadana; aunque por otro lado sea precisamente esa historicidad -el punto de vista prosaico de las preocupaciones

\footnotetext{
${ }^{22}$ Cfr. "Underdevelopment" (Raimondi, 2013a: 85).

${ }^{23}$ Las Cartas sobre la educación estética del hombre de Schiller serían el ejemplo paradigmático (1999 [1795]). Las premisas de la crítica marxista sobre el rol del arte clásico en la sociedad burguesa se hallan en El 18 Brumario de Luis Bonaparte. Otras perspectivas más variadas, aunque no excluyentes, sobre el tema pueden hallarse en Marx, Karl, Escritos sobre literatura, Buenos Aires, Colihue, 2003. Para un panorama de esos debates cfr. Bürger, 1996 [1983]; Eagleton, 1990.
} 
sociales- la que produce una fuerte contra-determinación en las nociones más convencionales de lo poético.

Al nivel del estilo pueden indicarse así dos movimientos convergentes: tal como decíamos, una contaminación de la imagen "objetiva" mediante toda clase de argumentos, datos económicos y referencias históricas y, al mismo tiempo, una segunda contaminación de "los clásicos" producida a partir del énfasis en una serie de gestos objetivistas: esto significa que la declamación, la hipérbole, la metáfora como estilización romántica de los autores greco-latinos son discutidos mediante la inclusión de otros elementos de ese discurso alineados con la propuesta de Helder, Prieto, Taborda, etc.: la hipotaxis, la claridad argumentativa, el detalle cotidiano, el léxico siempre explícito y referencial-que busca desautorizar cualquier gestualidad esotérica- sin dejar de sumar otras inflexiones como la frase estradiana o la descripción del proceso de trabajo con una fruición detallista solo hallable en Jauretche ${ }^{24}$. Ya sea entonces mediante las referencias a la montonera federal o una imagen tomada de Daniel Durand ("el sexo hundido en el frasco de tinta"), Ilegamos al punto en que las filiaciones clasicistas de Raimondi se encuentran con su opuesto absoluto. La ilusión de eternidad de la forma y los tópicos greco-latinos, máxima expresión del ideal de autonomía burgués, aparecen horadados por esa otra versión del discurso clásico que por el contrario tiende a historizarse a sí misma, buscando situar la expresión literaria más elaborada dentro de una circunstancia concreta. Esa estrategia retórica mostraría hasta qué punto la concepción de los "dos países" se pone de manifiesto al nivel del estilo; ella apuntaría a expresar la tensión entre los imperativos de un modelo productivo con sus respectivas expresiones culturales frente a un coyuntura parcial e insuficientemente percibida.

En el contexto inaugurado en 1983, el planteo de Raimondi se acerca así a la concepción de la lucha ideológica teorizada por Gramsci: no se trata de situarse por fuera de la cultura hegemónica, aquella con más prestigio y poder, sino más bien de intervenir dentro de las formas lingüísticas y estéticas a través de la cuales se expresan los valores de la ideología oficial -en términos gramscianos: el "sentido común"-. Esto le bastó a Poesía civil para garantizarse un lugar indiscutido

\footnotetext{
${ }^{24}$ Cfr. Los profetas del odio: "En las aradas y en el pasto encontró algún trabajo en invierno -cada vez menos-, pues la motorización lo eliminaba de las aradas y disminuía el consumo porteño de alfalfa. A fin de año, veinte o treinta días de trabajo en la cosecha fina -a su vez, la corta y trilla que reemplazaba la trilladora disminuía la demanda de brazos-, y después a esperar el maíz con los primeros fríos, donde trabajaba toda la familia en cuadrilla, a destajo por bolsa. ¡Pobres paisanos urbanos-rurales cuando se perdía una cosecha de maíz, sin pan y sin lumbre para todo el invierno! Quedaba sólo la cola en el comité o en la Municipalidad, para entrar en planilla una quincena cada dos meses, en esa beneficencia que son las peonadas de Comuna. Cuando se perdía una cosecha de maíz, todos se acordaban de la suerte del chacarero. ¿Quién de la del peón?" (Jauretche, 1957: 60-61, 65).
} 
dentro de la escena literaria sin dejar de referirse a cuestiones como la temática base-superestructura o la reflexión nacionalista. La combinación de retórica clásica e imagen objetivista logrará actualizar en el plano estético una preocupación que se había vuelto ilegítima, evitando la nostalgia o el simple homenaje. Y en términos de Pound, ese sería otro mérito de Poesía civil no suficientemente mencionado: darle nuevo valor comunicativo a una crítica reducida en los noventa a una variante retardataria del "populismo".

\section{Bibliografía}

Abelardo Ramos, Jorge (1985), Introducción a la américa criolla, Buenos Aires, Ediciones del Mar Dulce.

Aguirre, Osvaldo (comp.) (2014), La poesía en estado de pregunta. 10 entrevistas, Buenos Aires, Gog y Magog.

Aguirre, Osvaldo (2018), El campo, Rosario, Editorial Ivan Rosado.

Avaro, Nora (2016), "De lo figurado a lo literal", en La enumeración, Rosario, Nube Negra Ediciones, pp. 87-100.

Bürger, Peter (1996), Crítica de la estética idealista, Madrid, Visor.

Eagleton, Terry (1990), The ideology of the Aesthetik, Oxford, Blackwell Publishing.

Ferrer, Christian (2014), La amargura metódica, Buenos Aires, Sudamericana.

García Helder, Daniel (1990), El faro de Guereño, Buenos Aires, Libros de Tierra Firme.

----- (1993), El guadal, Buenos Aires, Libros de Tierra Firme.

----- (2007), "Aspectos materialistas en la poesía argentina", Cahiers de LI.RI.CO. Littératures contemporaines du Río de la Plata, $\mathrm{n}^{\circ}$ 3, pp. 131-148, [disponible en http://journals.openedition.org/lirico/780; DOI : 10.4000/lirico.780].

----- (2008), La vivienda del trabajador, Rosario, Editorial Municipal de Rosario.

González, Horacio (2001), Restos pampeanos. Ciencia, ensayo y política en la cultura argentina del siglo XX, Buenos Aires, Colihue. 
----- (2004), Filosofía de la conspiración: marxistas, peronistas y carbonarios, Buenos Aires, Colihue.

Gramuglio, María Teresa (2014), Nacionalismo y cosmopolitismo en la literatura argentina, Rosario, Editorial Municipal de Rosario.

Halperin Donghi, Tulio (1995), Proyecto y construcción de una nación (18461880), Buenos Aires, Ariel.

----- (2006), El revisionismo histórico argentino como visión decadentista de la historia nacional, Buenos Aires, Siglo XXI Editores [1970-1997].

Hernández Arregui, Juan José (2011), La formación de la conciencia nacional, Buenos Aires, Ediciones Continente.

Jauretche, Arturo (1957), Los profetas del odio y la yapa (la colonización pedagógica), Buenos Aires, A. Peña Lilo Editor.

---- (2013), Enfoques para un estudio de la realidad nacional. Conferencias pronunciadas por el Dr. Arturo Jauretche en la Universidad Nacional del Sur, los días 20 y 22 de Mayo de 1974, Buenos Aires, Corregidor.

Kesselman, Violeta et al. (comp.) (2012), La tendencia materialista. Antología crítica de la poesía de los 90, Buenos Aires, Paradiso.

Martínez Estrada, Ezequiel (1968), Radiografía de la pampa, Buenos Aires, Losada.

Marx, Karl (2003), Escritos sobre literatura, Buenos Aires, Colihue.

----- (2007), El 18 Brumario de Luis Bonaparte, Buenos Aires, Colihue.

Pas, Hernán (2007), “Una materialidad de la exasperación. Acerca de Poesía civil, de Sergio Raimondi", Orbis Tertius, n 13, [disponible en: http://www.memoria. fahce.unlp.edu.ar/art_revistas/pr.444/pr.444.pdf].

Porrúa, Ana (2003), "Ciudadanos y extranjeros. Sobre Poesía civil de Sergio Raimondi y Guatambú de Mario Arteca", Punto de vista, n 75, pp. 25-28.

Pound, Ezra (1977), El ABC de la lectura, Buenos Aires, Ediciones De la Flor.

----- (2018), Ensayos literarios, Madrid, Tajamar Ediciones. 
Raimondi, Sergio (1998), Catulito, Bahía Blanca, Ediciones Vox.

(2007), "Poesía y división internacional del trabajo. Sobre Estudios económicos de J.B. Alberdi", en Luis E. Cárcamo-Huechant, Alvaro Fernández Bravo y Alejandra Laera (eds.), El valor de la cultura, Rosario, Beatriz Viterbo.

----- (2010), Poesía Civil, Bahía Blanca, 17 grises editora [2001].

----- (2013), "Acá Platón hubiera echado a los peronistas, no a los poetas, de su República" [entrevista], Revista Mancilla, n 5, pp. 73-82.

---- (2013a), "Para un diccionario crítico de la lengua. Poemas inéditos", en Revista Mancilla, $\mathrm{n}^{\circ}$ 5, pp. 83-85.

---- (2014), "El sistema afecta la lengua", en Revista Mancilla, n 9, pp. 34-45.

Rubio, Alejandro (2005), Rosario, Buenos Aires, Gog y Magog.

---- (2012), "Raimondi y Rodríguez: lo privado y lo público más allá de la poesía de los '90", Revista Mancilla, n², pp. 14-23.

---- (2014), “Antiintelectualismo", Revista Mancilla, n 7, pp. 76-79.

Saer, Juan José (1994), El río sin orillas, Madrid-Buenos Aires, Alianza Editorial.

Scalabrini Ortiz, Raúl (2001), Política británica en el Río de la Plata, Buenos Aires, Editorial Plus Ultra.

Schiller, Friedrich (1999), Cartas sobre la educación estética del hombre, Barcelona, Anthropos, [Tr. Jaime Fijóo y Jorge Seca].

Sebreli, Juan José (1992), Los deseos imaginarios del peronismo, Buenos Aires, Editorial Sudamericana [1983].

Sarlo, Beatriz (1983), "La perseverancia de un debate", Punto de vista, n 18, pp. 3-5.

---- (1984), "La izquierda ante la cultura: del dogmatismo al populismo", Punto de vista, $\mathrm{n}^{\circ} 20$, pp. 22-25.

Tobarda, Oscar (1993), 40 watts, Rosario, Beatriz Viterbo. 
Terán, Oscar (1991), Nuestros años sesentas: la formación de la nueva izquierda intelectual en la Argentina, 1956-1966, Buenos Aires, Puntosur.

Vázquez, María Celia (2015), "Reinterpretación cultural e intervenciones críticas de la izquierda nacional: Jorge Abelardo Ramos y Juan José Hernández Arregui", Badebec, n9, pp. 315-339.

AA. VV. (1993), 18 whiskys, Buenos Aires, $n^{\circ} 3-4$. 
